\title{
Reflecting on reflections on COVID-19
}

\author{
Ynte K. VAN DAM, Joke F. WEBBINK \\ Wageningen University
}

\begin{abstract}
:
Aim: This paper is an invited reaction to Platje, Harvey \& Rayman-Bacchus, March 2020, 'COVID-19 - reflections on the surprise of both an expected and an unexpected event' in CEREM 4(1). In the tradition of critical science this paper starts from a discussion of the assumptions underlying the paper it reacts upon.
\end{abstract}

Findings: The original text is a laudable attempt to initiate a discussion on unpredictable future threats that remains constricted in semantic confusions, misperceptions, misinterpretations, and logical fallacies implying preconceived conclusions. As a logical consequence of a socio-economic system that systematically disregards human wellbeing and welfare - and exploits human weaknesses - in its endless pursuit of short term profit, the current pandemic and its subsequent crisis was expected and predictable, but wilfully ignored. And, unless this crisis will be used to rebuild the socio-economic system for sustainable development, so will be the next one.

Key words: COVID-19, Economy, Psychology, Sustainable Development

\section{Introduction}

Recent The March issue of CEREM published "COVID-19 - reflections on the surprise of both an expected and an unexpected event" (hereafter "REFLECTIONS") as an invitation to contribute to 'the discussion' and submit a reflection (Platje et al. 2020). As it was not clear which discussion was to be contributed to, the current contribution is a critical reflection. According to the first lines of its abstract REFLECTIONS reflects on the 2020 COVID-19 pandemic from the perspective of small probabilities and against the background of basic (and standard) economic

Correspondence address: Ynte K. VAN DAM, Joke, WEBBINK, Wageningen University, Hollandseweg 1, 6706KN Wageningen, The Netherlands. E-mail: ynte.vandam@wur.nl (Ynte van Dam), joke.webbink@wur.nl (Joke Webbink).

Received: 19.04.2020, Revised: 28.04.2020, Accepted: 28.04.2020

doi: http://dx.doi.org/10.29015/cerem.876 
principles. As implicitly promised the basic and standard economic assumptions themselves are not questioned. In our reflection we will briefly discuss the semantic confusions and economic confabulation of REFLECTIONS. Next we will discuss the socio-economic causes and consequences of the systematic crises of which the current pandemic is just one in a row of examples. Despite the opportunity to use this crisis to turn the tide and change the system towards sustainable development the authors foresee that all efforts will be geared toward further entrenching of the current disastrous system.

\section{Semantic confusion}

From the title onwards REFLECTIONS struggles with the meaning of 'unexpected' vs. 'expected' and 'unpredicted' vs. 'predicted'. First REFLECTIONS tries to classify the pandemic as a Black Swan (i.e. un unexpected, very unlikely event). REFLECTIONS pursues the black swan metaphor by comparing this pandemic to 'small probability events with potentially high impacts'. Consequently, the pandemic is dubbed 'an unexpected event that could have been expected to appear' (REFLECTIONS: 150), later refined into 'unexpected events that could be expected to appear unpredictably' (REFLECTIONS: 152). To confuse the issue even more REFLECTIONS mentions in passing that 'many predictions probably will not become reality' (REFLECTIONS: 151). At this point the reader may get irrevocably lost. If unexpected and unpredictable events are events that could have been expected to happen they must have been predicted. But if the unexpected has been predicted, and if predictions do not necessarily come true, then what is the meaning of 'unexpected' and 'unpredictable' in this context?

In fact the 2020 pandemic was neither unexpected, nor unpredicted, nor the first in our lifetime. REFLECTIONS quotes the inevitability of a pandemic in this globalised world from the Black Swan (Taleb 2007) so apparently it didn't require epidemiologic training to see it coming. Nor is global society very effective in managing pandemics, as claimed (REFLECTIONS: 152). For example HIV has been spreading unchecked since 1980. Rather than being managed effectively, HIV grew 
into a global pandemic with 3.3 million infections annually in 1997. Since then the HIV pandemic has been tamed into spreading by merely 2.6 million new infections annually around 2005 (GBD 2015), and 1.7 million new infections in 2018 (WHO 2020). Since the beginning of the HIV pandemic 75 million people have been infected, of whom 38 million were living with HIV in 2018 (WHO 2020). Likewise Ebola was first described in 1976 and rages intermittently till the present day, while its fatality rate is usually well over $50 \%$. Malaria, typhoid fever, cholera, and numerous other infectious diseases never were contained effectively either. Stating that we have managed many threats of epidemics shows a rather elitist worldview. We mainly managed to shift the burden of epidemics to the underprivileged majority on this planet. The 2002-2004 SARS outbreak, officially contained in 2003, convincingly has shown the effects of exponential infection in an unambiguous warning how fast a corona-type virus can spread across the planet. Since then the pandemic that eventually emerged as the Wuhan-virus just was an accident waiting to happen. It was bound to come, and it was increasingly likely to originate in China (Fan et al. 2019).

Already long before 2003 there have been warnings aplenty that the systematic destruction of the planets ecosystems will have repercussions that jeopardise human survival (Carson 1962; Meadows et al. 1972; WCED 1987). So what REFLECTIONS apparently means is that an expected and predicted event may hit our global political and economic system by surprise, because the most influential decisionmakers collectively and systematically deny and wilfully ignore predicted future disasters. Not because there is a small probability that it will happen but because, even though it is certain to happen sometime, there is a large probability that it will not happen in their tenure. This could be seen as a failure or weakness of the system. It is however far more correct to accept the empirical observation that this is the actual purpose of the current politico-economic systems on this planet. Empirically the 'purpose of a system is what it does' (POSIWID) nothing more and nothing less (Beer 2002). The majority of contemporary neo-liberal democracies and kleptocratic dictatorships have one common purpose. That purpose is the institutionalisation of direct private profit and greed by sacrificing long term human well-being and welfare (Steinzor 2012). Anyone who wants to change this shouldn't try to repair or change the 
existing system but should replace it by a radically different system with different institutions.

\section{Economy of bookkeeping}

REFLECTIONS builds on basic and standard economics, but is rather vague on what that entails. When using economics to discuss an ecological event it should be noted that economy and ecology share the same prefix, eco, derived from the Greek

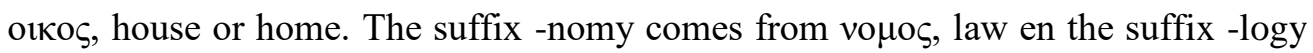
from $\lambda$ oyos, which is speech or word or consideration. So these suffixes refer to the laws of the house and the talks of the house. It is time to realise that we have these words mixed up disastrously. What we call ecology refers to the irrefutable and nomological laws of nature that apply to our planetary home. What we call economy refers to the socially constructed stories we tell each other on how to manage our housekeeping. Economy is just words and ecology is the law.

This notwithstanding the text turns rapidly to the law of 'cost benefit analysis in economics' (REFLECTIONS: 151). What REFLECTIONS fails to mention is that costbenefit analysis is a neo-liberal bookkeeping trick that favours short-term private profit over long term public investment (Driesen 2006). The cost-benefit state was introduced in the USA in the 1980s to counter the New Deal of the 1930s (Sunstein 1996). This effectively implied stripping the individual citizen of Roosevelt's governmental protection against many of the harms and risks of a market economy, such as unemployment, poverty, malnutrition, homelessness, lack of education, and hopelessness as a result of disability (Roosevelt 1944). The problem is not that cost benefit analysis does not provide the political and economic system with instruments that can handle rare and stochastic events. The problem is that cost benefit analysis is designed to preclude investing in future welfare and wellbeing. Cost-benefit analysis attempts to summarise the (long term) benefits in monetary value, and then discounts this 'revenue' over time to compare it to the short-term investments in terms of net present value. As long the analysis is used to choose among different investments with the same long term outcome it might be a useful tool, always 
assuming that all relevant outcomes and consequences can be known and measured. Quod Non (Sunstein 1996). When it is used to decide for or against investing in general, its apparent elegance hides the ugly fact that under cost-benefit analysis no sewerage or metro system would ever have been built and that environmental protection would be impossible (Ackerman et al. 2005). Long term benefits are systematically underrated (if only because the value of, e.g., preserving nature for infinity would be infinite), and discount rates systematically overstate current costs and understate future benefits (Kahneman, Tversky 1979). The simple observation that sewerage systems, metros, hospitals, and natural parks do exist should be an indication that cost-benefit analysis is a rather poor excuse for the myopia of the currently dominant politico-economic system.

In its economic analysis REFLECTIONS continues to explain that 'there ain't no such thing as a free lunch' (TANSTAAFL). The origin of the phrase is not known, but in its widely popularised use it means no more and no less than that everything has to be paid for by someone eventually (Heinlein 1966). As long as all the costs and benefits are one's own this indeed resembles, as REFLECTIONS claims, the opportunity costs of sacrificing of one benefit for another. The implication of TANSTAAFL however, is that any cost is either carried privately or shifted to someone else. In our current economic system the price of the majority of products and services is kept low by shifting the majority of the costs to (current or future) global society. This, like cost benefit analysis, is a rather recent invention. An extensive analysis of legal cases from medieval times to modernity show how the balance of TANSTAAFL has gradually shifted from private sacrifices for social benefits to widely condoned externalities and public sacrifices for the sake of immediate private profit (Coase 1960). By focusing on opportunity costs REFLECTIONS misses this point entirely. When banks and multinational companies were bailed out in the 2008 crisis, government budgets were balanced by budget cuts across the board. This indeed is not a choice between buying a hamburger or a steak. It also is not a choice between investing in holiday resort, airport, education, or health system. It is not even a choice between treating one patient or another (REFLECTIONS: 152). It is the choice to save banks that are 'too big to fail' at the expense of robust and resilient systems for health care and education. It is the choice 
for a society in which uncontrollable banks are indispensable and health care or education are not. And it has proven a choice for 'economising on spare capacity' and shifting the costs of emergency care with cumulative interest to the future where the crisis hits. And that future happens to be now. There just ain't no such thing as a free lunch.

\section{Heart of darkness}

REFLECTIONS takes a darker turn when discussing the precautionary principle as strategy to prepare for anticipated harm. The precautionary principle suggests that one takes time to review possible undesired consequences before wholeheartedly embracing innovations, in order to minimise the probability of foreseeable disastrous side-effects (Read, O'Riordan 2017). Conversely, where there are threats of serious or irreversible damage, lack of full scientific certainty shall not be used as a reason for postponing cost-effective measures to prevent environmental degradation (UN 1992). The requirement to actually delay the implementation of new technologies while considering undesired side-effects or possible backfiring is rather unpopular among neo-liberal adherents of deregulation, especially with respect to business. Opponents of the precautionary principle argue that finding convincing scientific proof of lack of harm could paralyse all innovation, which is a hyperbolic rhetorical twist of 'considering undesired side-effects'. The precautionary principle has subsequently been translated into the obligation to take measure to avoid disastrously harmful situations (that may cause systematic collapse) at all costs (Taleb et al. 2014 as quoted in REFLECTIONS), which just is not feasible - especially if the threatened system nurtures the seeds of its own destruction (Marx, Engels 1848).

The current pandemic is attributed to an unknown mutation of a minor common cold virus. At the time of writing it is unknown how long the virus survives outside its host, how long it takes to infect a new host, how contagious it is, how it moves from host to host, how many non-symptomatic carriers it breeds, how many symptomatic carriers die of the infection, whether non-symptomatic carriers will die 
of their infection two years from now, and so on and so forth. Nobody knows and everybody muddles through. This makes the current pandemic an exemplary wicked problem: everyone can define the problem and its cause in one's own way to derive one's favourite solution to the problem. Whatever measure is implemented to counter the crisis can be labelled anything from overreacting and creating panic to ignoring the seriousness and wilful negligence. Nobody knows, and if the long term consequences of any measure are unforeseeable then the precautionary principle warns against wholeheartedly embracing any single measure (Read, O'Riordan 2017). Here at least market theory, evolution theory, system theory, and the precautionary principle agree: trying the widest possible diversity of solutions offers the best chance of successful adaptation and survival - not necessarily for all individuals but for the species and the system.

Still in line with the precautionary principle REFLECTIONS argues that due to the current crisis the health care system is threatened in the short run, but the socioeconomic system in the long run (REFLECTIONS: 154). This is an interesting 'Umwertung aller Werten', because the current absence of a resilient healthcare system can be attributed to its being sacrificed by the socio-economic system to short term corporate profit and/or shareholder value. This is related to the problem of unseen evidence (REFLECTIONS: 152), combined with politics that are dominated by public opinion. The masses are more easily pleased with 'bread and circuses' than by successfully avoiding disasters that never occur. Even more perversely an avoidable crisis that is managed successfully also scores better in the media than a manageable crisis that is avoided successfully.

"From the economic point of view" REFLECTIONS continues, "should human life be saved at any cost?" (REFLECTIONS: 154). Preventing as many human deaths as possible may have serious economic consequences, and the spread of the virus may be considered a natural event. This hides the ugly truth that this epidemic, and many other so-called 'natural' disasters, are the result of systemic choices to expose people selectively to foreseeable and predictable threats (Kelman 2020). Pandemics may be natural events, but their consequences - selectively affecting polluted regions, socio-economic groups, ethnic minorities, or opponents of the incumbent regime - are socio-economic and political events. When REFLECTIONS discusses the 
affordability of offering health care and saving lives, it glosses over the fact that the word 'affordability' turns health care and living from a human right into a privilege. The current pandemic, like Ebola since 1976, like HIV since 1980, but also like the environmental destruction that continues unabated, like the innumerable refugee camps on this planet, all reveal the most sinister truth of our widely praised globalised socio-economic system: it doesn't care the least little bit about human lives, it only cares about profit and privilege.

In creating businesses (and nation-states) humans have created complex adaptive systems with emergent properties (Lansing 2003). By and large these systems are living their own lives (Draman 2004). Even if these supra-human systems were designed to serve humanity, they have evolved beyond mere servitude (North 1993; Wilkinson 2006) and they have come to ignore their humans. The interest of business is, and has always been, in some respect different from, and even opposite to, that of the public (Smith 1776). And it has long been known that without stringent regulation and control business will widen the market and narrow the competition to pursue its self-interest (Smith 1776). Eventually this unrestrained and self-interested business will undermine society by fostering normlessness (Durkheim 1893). By its own nature business is an enthusiastic supporter of fascism and totalitarianism. Therefore liberal (or neoliberal) economic policy, or any economic policy that defends the interests of business against the public, is an enemy of liberal democracy (Polanyi 1944; Popper 1945). This notwithstanding the liberal democracies of the world have aided in the creation supranational institutions that serve the interests of global business (like UN, IMF, World bank, WTO) and these institutions in turn have forced, lured or cajoled governments into neo-liberal unleashing of business.

\section{Living for the day}

Among the many weaknesses of the human species is the ineptness to handle psychological distance (Trope, Liberman 2010). Events that are remote in time or space, that concern unknown and anonymous people, and events that have unclear 
probabilities all are lumped in a category of psychologically distant and abstract (sur)reality. This implies a representation of reality in simplified general terms and evaluation in terms of desirability. Conversely events that occur here, now, to us, and for certain are psychologically proximal and concretely real. This implies representation of reality in detailed complexity and evaluation in terms of feasibility. The effects of psychological distance cover a wide range of cognitive and motivational effects that make us formulate the best possible resolutions for the future, while succumbing to temptation in the present (see, e.g. Van Dam, Van Trijp $2013,2016)$. So we build a roof for the rain but we continue living in the caldera of Naples. Rain will fall and the caldera will erupt, both unpredictably but the latter less often so we ignore this larger threat. Tomorrow we will start saving and tomorrow we will act sustainably and tomorrow we will prepare for disaster, but forever we live in the present and tomorrow is always a day away (Sherman, Sherman 1964). As long as long term goals and short term incentives reinforce each other humans seem perfectly reasonable, but when distant goals require systematically sacrificing pleasure in daily life the distant goal rapidly becomes a lost cause.

This fundamental human weakness has been effectively exploited by modern business. The ever present convenience and indulgence that modern business promises overshadows the psychologically distant costs to health, the environment, and livelihoods. This fundamental human weakness is cleverly exploited by a neoliberal global economic system that provides instant gratification to some in the present with an exponentially growing debt to others and the future. This debt to the future was in economic terms over $300 \%$ of GDP globally before the current crisis hit the economy (Global Debt Monitor). In ecological terms this debt is that humanity uses 1.75 planet annually to support the global economy (Foot print network), and that human activity increasingly encroaches on wildlife habitats increasing the spill-over of viruses from natural hosts to humans (Cui et al. 2019). In socio-economic terms this debt means, e.g., child labour, discrimination, poverty, inaccessible healthcare, and/or inaccessible education (ILO, s.d.). And this debt has meant being unprepared for a pandemic that was neither unexpected nor unpredicted, but wilfully ignored for the sake of the growing GDP's of the past. 


\section{Concluding remarks}

Humanity is duped by the short-sighted self-interest of world leaders who maintain and nurture a global socio-economic system that has outgrown its creators. This global socio-economic system repeatedly has displayed that its purpose is to destroy people, planet, and prosperity. Whether it is by the financial crisis of 2008, by ignoring pandemics that 'only hit homosexuals and/or sub-Saharan Africans', by nonchalant indifference to people rotting away in refugee camps all over the planet, or by the denial, disinformation, and political opportunism surrounding the current pandemic: the bankruptcy of the current socio-economic and political system has become increasingly clear over the past few decades. The discussion therefore should not be on unpredictable future threats, but on a global political and socioeconomic system wilfully ignoring predicted future disasters.

People are supposed to believe that global economy is in a lockdown, and that a collapse of stock markets or evaporation of shareholder value is disastrous. This is one way of looking at it, but the reverse view is that the essential economy continues as ever. This is the economy that runs our household. Food is grown, care and cleaning are provided, education continues. If these services fail to reach those who need it that is a consequence of the current socio-economic system and not of its collapse If these activities are not considered valuable in our current socio-economic system that is just another reason to get rid of this system and those who serve it. Let's face it: the current economic system of oligarchic capitalism or corporate plan economies is a vastly expensive fiction to provide the most useless people with the highest income, and the most productive people with the lowest income (Smith 1776). From a human point of view, the real question is, should this economic system be saved at any cost? For mainstream economists this may sound horrible, but considering the socio-economic consequences of this current pandemic, the issue is relevant. For once ignoring the habitual selective blindness: when considering the visible consequences of this totally corrupted and bankrupt system, preventing and postponing its inevitable collapse may have serious socio-ecological consequences.

It has taken a pandemic, and especially the global fear of its seriousness, to give our global ecosystem the first months of breathing space in decades, or even 


\section{REFLECTING ON REFLECTIONS ON COVID-19}

centuries. This might be a perfect moment to restart with a green slate, and force the economy to rebuild itself in line with sustainable development. The former French president and ex general Charles de Gaulle is reputed to have said that 'l'économie c'est l'intendance, et l'intendance suivra', the economy, like a supply corps, follows - no one in a right mind would let it set the course. But of course letting the economy set the course is exactly what will happen with governments who serve business rather than people. So at the next systemic crisis don't tell me that it is surprising, or that is unexpected and unpredictable. It will be just the next disaster that is waiting for its perfect moment to happen.

\section{Acknowledgements}

The authors acknowledge Joseph Conrad and Patrick Burgener as original authors of the titles of sections 4 and 5 in this paper.

\section{References}

Ackerman F., Heinzerling L., Massey R. (2005), Applying cost-benefit to past decisions. Was environmental protection ever good idea, “Administrative Law Review”, vol. 57 no. 1, pp. 155-192.

Beer S. (2002), What is cybernetics, "Kybernetes", vol. 31 no. 2, pp. 209-219.

Carson R. (1962), Silent spring, Houghton-Mifflin, Boston.

Coase R. (1960), The problem of social cost, “Journal of Law and Economics”, vol. 3, pp. 1-44.

Cui J., Li F., Shi Z.-L. (2019), Origin and evolution of pathogenic coronaviruses, "Nature Reviews Microbiology", no. 17 (March), pp. 181-192.

Draman R.H. (2004), Organization/business, management, people and complexity - an approach to their integration, "Human Systems Management", vol. 23 no. 2, pp. 101-110.

Driesen D.M. (2006), Is cost-benefit analysis neutral, "University of Colorado Law Review”, vol. 77 no. 2, pp. 335-404.

Durkheim E. (1893), De la division du travail social, Félix Alcan, Paris.

Fan Y., Zhao K., Shi Z-L., Zhou P. (2019), Bat coronaviruses in China, "Viruses", vol. 11 no. 3, p. 210. 
Foot print network (s.d.), https://www.footprintnetwork.org/our-work/ecological-footprint/ [04.04.2020].

GBD 2105 HIV Collaborators (2016), Estimates of global, regional, and national incidence, prevalence, and mortality of HIV, 1980-2015. The Global Burden of Disease Study 2015, "The Lancet. HIV", vol. 3 no. 8, pp. e361-e387.

Global Debt Monitor (2020), https://www.iif.com/Research/Capital-Flows-and-Debt/Global-DebtMonitor [04.04.2020].

Harari Y.N. (2019), Sapiens - a brief history of humankind, Vintage, London.

Heinlein R.A. (1966), The moon is a harsh mistress. G.P.Putnam's Sons, New York.

ILO (s.d.), https://www.ilo.org/global/topics/working-conditions/lang--en/index.htm [04.04.2020].

Kahneman D., Tversky A. (1979), Prospect theory. An analysis of decision making under risk, "Econometrica", vol. 47 no. 2, 263-291.

Lansing J.S. (2003), Complex adaptive systems, “Annual Review of Anthropology”, vol. 32, pp. 183204.

Marx K., Engels F. (1848), Manifest der kommunistischen Partei, Bildungs-Gesellschaft für Arbeiter, London.

Meadows D.H., Meadows D.L., Randers J., Behrens 3rd W.W. (1972), The limits to growth, Potomac Associates, Falls Church.

Nicholson N. (1998), How hardwired is human behavior?, "Harvard Business Review", vol. 76 no. 4 , 134-147.

North D. (1993), Economic performance through time, Nobel Prize Lecture, https://www.nobelprize.org/prizes/economic-sciences/1993/north/lecture/ [01.05.2020].

Platje J., Harvey J.A., Rayman-Bacchus L. (2020), COVID-19 - reflections on the surprise of both an expected and unexpected event, "CEREM", vol. 4 no. 1, pp. 149-162.

Polanyi K. (1944), The great transformation, Farrar and Rinehart, London.

Popper K. (1945), The open society and its enemies, Routledge, London.

Read R., O'Riordan T. (2017), The precautionary principle under fire, "Environment: Science and Policy for Sustainable Development”, vol. 59 (Sept/Oct), pp. 4-15.

Roosevelt F.D. (1944), Message to the Congress on the State of the Union, January 11.

Sherman R.M., Sherman R.B. (1964), There's a great big beautiful tomorrow, Walt Disney Corp.

Steinzor R. (2012), The age of greed and the sabotage of regulation, "Wake Forest Law Review", vol. 47 no. 3, pp. 503-536. 


\section{REFLECTING ON REFLECTIONS ON COVID-19}

Smith A. (1776), An inquiry into the nature and causes of the wealth of nations, W. Strahan and T. Cadell, London.

Taleb N.N., Read R., Douady R., Norman J., Bar-Yam Y. (2014), The precautionary principle. Fragility and black swans from policy actions, Extreme risk initiative - NYU School of Engineering Working Paper Series, https://www.fooledbyrandomness.com/pp2.pdf [01.05.2020].

UN (1992), Agenda 21. Rio declaration on environment and development, United Nations Conference on Environment \& Development, Rio de Janeiro.

Van Dam Y.K., Van Trijp H.C.M. (2013), Relevant or determinant. Importance in certified sustainable food consumption, "Food Quality and Preference", vol. 30 no. 2, pp. 93-101.

Van Dam Y.K., Van Trijp H.C.M. (2016), Interventions to encourage sustainable consumption, "APSTRACT: Applied Studies in Agribusiness and Commerce", vol. 10 no. 2-3, pp. 51-58.

WCED (1987), Our common future, Oxford University Press, Oxford (UK).

WHO (2020), Global Health Observatory (GHO) Data, https://www.who.int/gho/hiv/en/ [04.04.2020].

Wilkinson I. (2006), The evolvability of business and the role of antitrust, "The Antitrust Bulletin", vol. 51 no. 1 , pp. 111-141. 